\title{
МАНИПУЛЯЦИИ ОБЩЕСТВЕННЫМ СОЗНАНИЕМ В ЭКОЛОГИЧЕСКОМ КОНФЛИКТЕ НА КУШТАУ
}

\author{
К.И. Горбачева
}

\author{
(carriestr@gmail.com) \\ Межрегиональная экологическая общественная \\ организация «ЭКА», \\ Москва, Россия»
}

Цитирование: Горбачева К.И. Манипуляции общественным сознанием в экологическом конфликте на Куштау // Власть и элиты. 2020. Т. 7, № 1. С. 204-231.

DOI: https://doi.org/10.31119/pe.2020.7.1.8

Аннотация. Статья описывает результаты исследования гражданского протеста в Республике Башкортостан против уничтожения объекта всемирного геологического наследия горы-иихана Куштау. Предмет исследования - манипуляциии общественным сознанием в экологическом конфликте и их преодоление. Исследование основано на теории манипуляиии общественным сознанием, которая объясняет достижение определенного уровня согласия в обществе, а также пассивное поведение в ситуации социального конфликта через использование манипулятивных приемов в информационной политике. Автором проанализированы разные каналь распространения информации по теме Куштау на предмет наличия в них признаков применения манипулятивных приемов. Также анализировались материалы в СМИ и других информачионных источниках для определения соответствия предлагаемых различными акторами образов ситуации реальному положению дел. Систематизированы приемы манипуляций. Проанализированы данные глубинных интервью, позволивщие определить уровень информированности выходиев из Башкортостана, ныне проживающих в других российских регионах, о проблеме промышленной разработки шихана Куштау. Рассмотрен механизм преодоления манипулятивного воздействия, использованный общественным движением в защиту Куштау, что привело в итоге к решению властей о сохранении горы и обеспечении ее государственной защитой.

Ключевые слова: манипуляции общественным мнением, массовое сознание, каналы распространения информаиии, средства массовой информачии, экологическое движение, гражданское общество, сетевое участие. 


\section{ВВЕДЕНИЕ}

В последние десять лет наблюдается рост и обострение экологических проблем в России. Увеличивается количество свалок (в том числе несанкционированных), осуществляются планы по строительству особо крупных полигонов для размещения отходов и мусоросжигательных заводов, ввозятся для захоронения и утилизации радиоактивные отходы, в промышленных масштабах рубятся леса (в том числе для вывоза за рубеж), загрязняются выбросами и сбросами воздушное и водное пространство страны, с нарушением законодательства добываются полезные ископаемые, предпринимаются многочисленные попытки ведения хозяйственной деятельности на ООПТ, а также изменения (сокращения) их границ. Часто проблема не получает должного освещения, что создает у населения ложное представление о состоянии окружающей среды. Заблуждения о реальном положении дел в сфере экологии приводят к безучастному отношению граждан к решению проблем. Этим же объясняется и низкий уровень активности «зеленых» партий и их поддержки электоратом.

Доведение сведений о происходящих процессах до широких масс населения происходит в первую очередь посредством государственных и негосударственных СМИ. Однако появление той или иной темы в повестке дня газет, журналов, интернет-изданий определяет их редакционная политика. Характерно, что новости об экологических проблемах попадают на страницы изданий только на стадии тяжелого обострения ситуации (например, как в случае экокатастроф в Норильске, на Камчатке или массовых беспорядков на Шиесе, Куштау) и/или после того как проблема стала активно обсуджаться в социальных сетях. При этом говорить об объективности СМИ не приходится - во многих случаях информация преподносится однобоко, что ставит вопрос о заинтересованности третьих лиц, влияющих на ракурс освещения проблемы. Подобным образом обстоит проблема с информацией, исходящей из государственных органов и от должностных лиц: часто о напряженных экологических ситуациях официальные лица заявляют едва ли не последними (ситуация на Камчатке, в Шиесе, Сибае и в других точках).

Таким образом, в России складывается ситуация, при которой экологические проблемы редко и с трудом становятся объектом внимания, а когда становятся - подаются в СМИ и официальных каналах распространения информации односторонне. Одновременно серьезные 
противоречия в сфере природопользования и охраны окружающей среды, а также противостояния местных жителей с промышленниками и органами власти наблюдаются почти в каждом регионе, и их количество увеличивается. Замалчивание проблем создает ложное ощущение стабильности, которое имеет свой предел и однажды провоцирует взрыв в результате обнаружения населением разрыва между образом реальности, который был сформирован в общественном сознании, и самой реальностью. В условиях экономического кризиса, а также роста общественного недовольства политикой государства это может быть одним из факторов дестабилизации политической ситуации в стране. Такая тенденция становится заметна и самому обществу, которое, видя негативные последствия замалчивания экологических проблем, предпринимает действия по преодолению информационной блокады, что, в свою очередь, медленно, но приводит к конструктивному решению наиболее острых экологических конфликтов в России.

Одним из таких примеров стало преодоление блокады в освещении угрозы уничтожения объекта всемирного значения горы Куштау в Республике Башкортостан, где в результате донесения объективной информации о проблеме до широкой российской и зарубежной общественности стало возможным принятие на уровне государства решения о сохранении природного объекта путем присвоения ему природоохранного статуса.

\section{ПОСТАНОВКА ПРОБЛЕМЫ}

В 2020 г. 14 и 15 августа в Республике Башкортостан произошли массовые столкновения на горе Куштау, ставшие кульминацией спора за гору между сторонниками ее сохранения как ценного природного объекта и сторонниками ее использования (и как следствие уничтожения) в качестве месторождения известняка для содовой промышленности. В региональных СМИ долгое время доминирующей позицией по поводу будущего горы было мнение сторонников разработки, а в федеральных проблема и вовсе была представлена слабо.

Главными субъектами, заинтересованными в разработке Куштау, выступали компании "АО “Башкирская содовая компания” (по производству соды) и “АО “Хайдельбергцемент Рус"» (по производству цемента), а также АО «Сырьевая компания», их дочернее предприятие, выполняющее добывающие работы. Однако ведущим субъектом в ин- 
формационном пространстве, озвучивающим планы о разработке, стал глава Республики Башкортостан Радий Хабиров, который первым выразил такую позицию в декабре 2018 г. Субъектом, принимающим решение о возможности разработки, был не региональный, а федеральный орган власти: филиал Федерального агентства по недропользованию Департамент по недропользованию по Приволжскому федеральному округу. Из этого вытекает вывод, что глава Башкортостана косвенным образом озвучивал в регионе позицию федерального органа власти (в том числе досрочно, так как лицензия на добычу полезных ископаемых из Куштау была выдана в 2019 г.), а также позицию содовой и цементной компаний, поскольку, хотя в медийном пространстве предприятия не выдвигали требования о передаче им горы Куштау, документы на получение лицензии на добычу известняка для содовой и цементной промышленности подавало именно их дочернее предприятие.

С помощью определенных каналов информации происходила попытка внедрить в общественное сознание положительный образ такого решения, которое преподносилось как «оптимальное», «консенсус». Выборочное преподнесение информации только о его плюсах привело к длительному отсутствию какого-либо четкого возражения со стороны обычных граждан вследствие непонимания ими последствий принимаемого решения. И только после объединения отдельных граждан в общественное движение за сохранение горы Куштау и их планомерной просветительской работе информационное пространство постепенно наполнилось сведениями о наличии альтернативной позиции о судьбе горы и решении проблемы бесперебойного производства кальцинированной соды (продукт, для создания которого использовался известняк).

Интенсивность донесения информации об угрозе уничтожения природного объекта нарастала по мере приближения к началу работ. Отсутствие ясных законных механизмов по отмене разрешения на разработку Куштау и понимание серьезности намерений добывающей компании побуждало скептически настроенную общественность активнее распространять информацию о ситуации. Начало работ в августе 2020 г. объединило вокруг активистов всех сочувствующих граждан и побудило их на решительную просветительскую деятельность. После обнаружения следов рубки деревьев на горе (1-2 августа) информационное противостояние приобрело характер информационной войны, которую выиграли активисты к вечеру 14 августа (несмотря на физический разгром экозащитников в результате «битвы» на горе). Этому 
способствовало широкое освещение ситуации не только в России, но и в других странах.

Однако длительное замалчивание сведений о проблеме, преподнесение решения о разработке как общественного «консенсуса» накладывались на нежелание со стороны производственников и органов региональной власти находить действительно конструктивное решение проблемы. Это привело к гражданскому противостоянию, в котором столкнулись силы не только активистов-экозащитников и государства в лице полиции, но и силы, поддерживающие интересы предприятия, в лице сотрудников завода и так называемых «титушек». Ситуация, минуя стадию переговоров, приобрела характер силового подавления несогласных. Целью стало принудить их к отказу от своей точки зрения и изменение общественного мнения. Накал обстановки был настолько силен, что общество в регионе буквально разделилось на два лагеря.

\section{КОНЦЕПТУАЛЬНАЯ ОСНОВА ИССЛЕДОВАНИЯ}

Теория манипуляций общественным сознанием дает подробное объяснение информационной политике, выстраиваемой вокруг крупных экологических проблем в России. Манипуляцию рассматривают как систему психологического воздействия, направленного на насаждение кажущегося мировосприятия [Черникова 2015].

С.Г. Кара-Мурза отмечает, что «согласно Грамши, власть господствующего класса держится не только на насилии, но и на согласии. Механизм власти - не только принуждение, но и убеждение» [Кара-Мурза 2015]. Необходимый уровень согласия обеспечивает функционирование государства. При этом требуется активное благожелательное согласие граждан. Таким образом, опираясь на концепцию, согласно которой поддержание определенного, желательного порядка требует определенного уровня согласия в обществе касательно ключевых вопросов, можно сделать вывод о том, что манипуляция сознанием масс служит тем самым инструментом достижения такого согласия, заменяя опору на здравый смысл людей.

С.Г. Кара-Мурза приводит перечень приемов политической манипуляции, среди которых прямая ложь, умолчание достоверной информации, в том числе о целях, цене и сроках достижений, стереотипы, игра на чувствах, подмена понятий, игра числом и мерой и др. [КараМурза 2015]. Он уточняет, что прямая ложь сама по себе не может быть 
квалифицирована как манипуляция, но множество мелкой явной лжи используется с целью уточнения порога восприятия ее людьми (подпороговые культурные явления). Однако в то же время мелкая ложь используется как эффективный прием воздействия все чаще в связи с высокой плотностью подачи информации и маловероятностью ее разоблачения с заметным резонансом. Одна из целей использования такой лжи - разрушение возможности диалога.

К средствам манипуляции общественным сознанием относят печатные издания, телевидение, интернет, радио, которые также являются каналами распространения информации. К ним также можно отнести публичные выступления [Зелинский 2008].

Среди принципов манипуляции сознанием выделяют последовательность, авторитет, благосклонность, взаимный обмен, заразительность и дефицит (нехватку) [Зелинский 2008]. С. Зелинский также приводит наиболее полный перечень принципов манипуляции массовым сознанием посредством СМИ: принцип первоочередности, эмоциональное заряжение, недоступность информации (информационная блокада), смещение акцентов (а также схожие принципы «переориентация внимания», «показная проблематика», «одностороннее освещение событий»), удар на опережение, эффект «информационного штурма», эффект правдоподобия, обратный эффект, будничный рассказ, экспрессивный удар, использование «лидеров мнений» или одобрение мнимого большинства, «очевидцы событий (или «эффект присутствия»), образ врага, ложные аналогии, или диверсии против логики, искусственное «просчитывание» ситуации, манипулятивное комментирование, допуск (приближение) к власти, повторение.

Особенность успешной манипуляции общественным сознанием заключается в том, что даже при обнаружении факта манипуляции истинная цель не может быть выявлена. В.Е. Черникова полагает, что «являясь скрытым воздействием на массовое сознание, манипуляция, как правило, нацелена на формирование инертности народных масс» [Черникова 2015]. В свою очередь, концепция «спирали молчания» Э. Ноэль-Нойман объясняет учет человеком окружающей его согласованности мнения или поведения при формировании своей позиции, что в результате влияет на возникновение общественного мнения [НоэльНойман 1996].

Раскручивание и внедрение манипулятивной идеи происходит посредством осуществления первичной и вторичной манипуляции, где 
первое является продуманным действием заказчика и исполнителя, знающих цель и приемы манипулирования, а второе - плодом первой, таким манипулированием, которое может осуществляться исполнителями без осознания ее как негативного действия [Горина 2016].

\section{МЕТОДОЛОГИЯ ИССЛЕДОВАНИЯ}

Для проведения исследования изучались каналы массовой информации и коммуникации: а) СМИ (государственные и негосударственные, федеральные, региональные, местные); б) социальные сети (аккаунты в Instagram главы республики Башкортостан, АО «Башкирская содовая компания», а также аккаунты, посвященные защите природы; страницы в соцсети «ВКонтакте»: группа общественного движения в защиту Куштау — «Сохраним Шиханы Торатау, Юрактау, Куштау», территориальные группы г. Стерлитамака); в) чаты в мессенджерах Whatsapp и «Телеграм»; информационные каналы в «Телеграм» и на YouTube; г) сайты региональных органов власти АО «Башкирская содовая компания», некоммерческих природоохранных организаций (в том числе «Greenpeace» и «Эковики»); д) официальные выступления государственных должностных лиц и руководителей АО «Башкирская содовая компания». Публикации, сообщения и выступления проанализированы на предмет наличия оценочных слов-«маркеров», выражений, допускающих неопределенность в толковании, подмену понятий, противоречивых числовых данных. Для проверки фактологической точности проводился анализ нормативно-правовых документов, а также научных источников с целью дальнейшего сравнения с информацией, используемой в высказываниях официальных лиц, лидеров общественного мнения, в материалах общественных активистских групп.

Для фиксации и анализа общественного мнения за пределами Башкортостана о проблеме в начальный период освещения решения о разработке Куштау проводились глубинные интервью $(\mathrm{N}=14)$ с гражданами - выходцами из Республики Башкортостан, проживающими в том числе за рубежом.

Сведения о способах преодоления информационной блокады и других манипулятивных приемах, касающихся будущего горы Куштау, были получены путем наблюдения за действиями активистов, в результате интервью, а также посредством личного участия автора в информационной кампании по защите природного объекта. 


\section{РЕЗУЛЬТАТЫ}

Информационная политика стороны, планирующей разработку Куштау, заключалась в том, чтобы показать:

1) решение: а) принято, б) не требует обсуждения, в) основано на экспертном подходе, г) поддерживается большинством, соответствует ценностям большинства

2) отказ от принятого решения приведет к отрицательным последствиям для значительной части общества;

3) его противники: а) желают вреда для общества, б) представлены опасными элементами, в) представляют враждебные для общества силы.

Замалчивались важные сведения, учет которых мог повлиять на формирование общественного мнения о проблеме, в том числе научные экспертизы и информация о негативных последствиях предлагаемого решения. Подменялась информация о лицах, принимающих решение. Одними из главных приемов манипуляции общественным мнением были принцип контраста, одностороннее освещение событий и преподнесение информации («правда наполовину»), использование лидеров мнений, показная проблематика, недоступность информации, образ врага.

Важными каналами трансляции позиции о разработке горы стали аккаунты в соцсетях главы республики Радия Хабирова (Instagram) и главного политтехнолога администрации Р. Мурзагулова (Facebook), который возглавлял совет директоров информационного агентства «АО “Башинформ”». В свою очередь, информационное агентство «Башинформ» координировало деятельность государственных региональных СМИ. В республике сформировался круг СМИ, которые повторяли или развивали позицию главы Башкортостана о планах разработки горы. Также активно действовал анонимный телеграм-канал «Техас Хабирова», который последовательно транслировал резкое отношение к защитникам горы. Поддерживающую функцию выполняли аккаунты содовой компании в социальных сетях (Instagram - @etosoda, «ВКонтакте” - «Сода пищевая», «АО «Башкирская содовая компания»), а также заводские сайт, газета «Вестник содовой компании», радио, направленные на формирование положительного имиджа предприятия.

Каналами распространения альтернативных точек зрения, объективных (в том числе научных) данных, недостающей информации, развенчания мифов, просвещения стали социальные сети (группы в «ВКон- 
такте» - «Сохраним Шиханы Торатау, Юрактау, Куштау», «Урняк-Куштау», «Куштау - мой дом», «Юг Башкортостана», территориальные группы г. Стерлитамака и других населенных пунктов; аккаунты в Instagram - «Shihan of Bashkortostan», «Live2film»), мессенджеры (Whats'app, Telegram), YouTube-видеохостинг, нейтральные СМИ, листовки, переписка, личное общение, плакаты на пикетах, наклейки на машинах и даже одежда (например, футболки с дизайнерскими принтами в защиту горы), выступления на мероприятиях (например, на круглых столах, организуемых Советом по правам человека при Президенте РФ, газетой «Bonus», партией КПРФ, Общественной палатой РФ, на форуме «Общероссийский гражданский форум»). В условиях информационной блокады защитники горы использовали в качестве канала распространения информации любую возможность, вплоть до символов в публичном пространстве (например, одежды с надписью «Куштау» или рисунком горы).

\section{ПРИЕМЫ МАНИПУЛЯЦИИ ОБЩЕСТВЕННЫМ МНЕНИЕМ НА КУШТАУ}

Принцип контраста. Решение о разработке Куштау было преподнесено на фоне длительного спора вокруг судьбы других двух шиханов - Торатау и Юрактау. Весной-летом 2018 г. набрало силу противостояние за гору Торатау, в котором представители АО «Башкирская содовая компания» утверждали, что для получения известняка для содового производства необходима разработка именно этой горы. Однако шиханы Торатау, а также Юрактау имели статус особо охраняемой природной территории регионального значения (памятник природы). Представители компании требовали снять природоохранный статус с горы. Общественность активно выступила в защиту и в мае 2018 г. провела многотысячный флешмоб «Кольцо жизни». Поэтому решение о разработке Куштау на фоне борьбы за сохранение другой горы преподносилось как «оптимальное» решение предыдущего спора.

В БСК настаивали, чтобы власти передали гору Торатау, наиболее подходящую, по мнению компании, по химическому составу для производства соды. Но врио главы республики Радий Хабиров настоял на том, что если речь идет о разработке шиханов, то это может быть только Куштау. Так что компромиссное решение, - сообщили в правительстве республики [Чернова 2018]. 
Одностороннее освещение событий и преподнесение информации («правда наполовину»). Для создания положительного образа $\mathrm{AO}$ «Башкирской содовой компании» повсеместно подчеркивалась его роль в развитии Башкортостана. Положительный образ компании мог повысить доверие населения к ее действиям и способствовать согласию людей со всеми решениями, включая планируемую разработку горы. При этом давалась только положительная информация о предприятии (обеспечение города рабочими местами, помощь городу и республике, в том числе в организации культурно-массовых мероприятий, финансирование новогоднего украшения площадей в городах республики), негативная умалчивалась (вклад предприятия в загрязнение воздуха и воды, отсутствие существенного роста зарплаты рядовых сотрудников, отмена «вредности» на производстве, отказ от финансирования объектов социальной инфраструктуры, обеспечивавшихся за счет предприятия с момента его основания, - больниц, футбольного клуба, Дома культуры, детских лагерей и санаториев).

Вслед за Убой на улицах Стерлитамака появились уникальные новогодние инсталляиии итальянского мастера Валерио Фести.

«Вместе со всеми горожанами мы разделяем восхищзение от мастерства художников, - делится впечатлениями генеральный директор БСК Эдуард Давыдов. - Башкирская содовая компания традииионно вносит большой вклад в новогоднее оформление города. И мы охотно откликнулись на предложение региональных властей профинансировать новогодние световые инсталляиии в Уфе и Стерлитамаке, поскольку считаем, что такие проекты создают праздничное настроение сотням тысяч людей» [На средства БСК 2019].

Разобрать подобную однобокость в преподнесении информации можно на примере позиционирования отношения компании к массовому спорту:

Поддержка массового спорта особенно - это в первую очередь забота о здоровье наших детей, а значит, о будущем сильной странь, считают в компании [Социальная политика БСК 2017].

Грант БСК позволил вывести соревнования на новыци уровень.

В эти выходнье, 8 и 9 декабря в ледовом двориее Стерлитамака состоялся IV Кубок Урала и Поволжья по всестилевому каратэ на призы Башкирской содовой компании [Семина 2018].

Примеры высказываний показывают, как формируемый образ вступает в противоречие с фактами, которые остаются неосвещенными. 
В данном случае уместным будет упоминание остановки финансирования клуба «Содовик» в 2006 г., которое произошло через некоторое время после смены владельцев предприятия ОАО «Сода» (прежнее название компании). За год до этого команда вошла в первый дивизион и показала свой лучший результат за время существования клуба с 1961 г. Значение клуба подтверждает цитата главного тренера команды Александра Игнатенко:

Проделан огромный объем работы, коллектив находился не на последних ролях в первом дивизионе. На следующий год планировался выход в премьер-лигу. Я не усльшиал ни одного аргумента в пользу ликвидации «Содовика». По сути, у 250-тысячного города забрали главное зрелище. А в футбольном плане речь идет о масштабах всей Республики Башкирия. «Содовик» - единственная команда мастеров, в которую стремились попасть большинство талантливых футболистов республики [Жировкин 2006].

Учет предыдущих действий субъекта позволяет сформировать полноценное представление о нем. Но направленность СМИ на размещение информации, касающейся только конкретного события, в длительной перспективе мешает формированию к нему объективного отношения. Намеренное создание публикаций лишь в положительном ключе усиливает эту тенденцию.

Показная проблематика. Проблема обеспечения предприятия известняком преподносилась как проблема его функционирования. В случае неполучения разрешения на добычу предприятие, по заверениям его руководителей, должно было закрыться. Тем самым нагнеталась паника в связи с сохранением рабочих мест (от 4 до 10 тысяч) и обеспечения страны содой как стратегическим продуктом. При этом не учитывалось, что в результате разработки Куштау ухудшится жизнь более пяти тысяч жителей населенных пунктов вокруг горы. Также не говорилось о том, что всего на АО «БСК» работают десять тысяч сотрудников, в то время как производство кальцинированной соды ведется лишь в одном из цехов, что означает невозможность закрытия всего предприятия, так как речь идет лишь о возможном закрытии одного из цехов. Проблема разработки Куштау сводилась к проблеме функционирования завода, в то время как в соответствии с данными ученых она могла быть решена путем разработки альтернативных месторождений или использования безызвестняковых технологий. 
Я никогда не соглашусь оставить без работь тысячи тюдей. Бесполезно пытаться меня ломать, выкручивать руки, подкупать журналистов и националистов. Это пьттаются делать те, кто просто хотят выдавить одну компанию с рынка и запустить свою, - глава Республики Башкортостан Р. Хабиров в своем Послании Государственному собранию - Курултаю Республики Башкортостан в 2019 г. [Хабиров 2019].

Свою позицию я уже высказывал - Куштау будет разрабатываться. Да нам никто и не позволит остановить стратегчческое для страны производство и оставить без работы тысячи людей, - подчеркнул Радий Хабиров [на встрече с представителями научного сообщества] [В Башкортостане создадут 2020].

[Р. Хабиров] не побоялся заявить перед выборами непопулярную позицию о возможности разработки Куштау, чтобы сохранить стратегически и экономически важное предприятие, от работы которого зависит благополучие почти 50 тысяч человек республики. И эта честная позиция была поддержана подавляющей частью населения - более 82 процента, пришедших на выборы и почти 2/3 всех жителей республики отдали за него свои голоса на выборах в сентябре 2019 года, - руководитель регионального исполкома «Единой России» и вице-спикер Госсобрания - Курултая РБ Р. Ахмадинуров [Фатхуллина 2020].

Здесь также манипуляция цифрами - факт голосования 2/3 жителей Башкортостана за Радия Хабирова на выборах главы региона преподносится как согласие большинства граждан с решением о разработке Куштау, однако поддержка кандидата в ходе голосования может быть объяснена и другими причинами.

Использование лидеров мнений. Решение разрабатывать Куштау сопровождалось комментариями лидеров общественного мнения о том, что это разумное и эффективное решение проблемы сохранения Торатау.

Я полностью поддерживаю решение Радия Хабирова. Наконеи-то в этом деле поставлена точка. У нас в Башкирии достаточно шиханов. В результате решения проблемы на БСК останутся рабочие места, Р. Утяшева, зампредседателя комитета по здравоохранению, социальной политике и делам ветеранов Госсобрания Башкирии [Беляев 2018].

Разработка Куштау - это миллиарды долларов в бюджет республики. Десятки тысяч рабочих мест. Вопрос отдать Куштау или не отдать, к сожалению, не стоит уже давно, - певец Элвин Грей (Радик Юльякшин) [Грей 2020]. 
Недоступность информации (замалчивание, информационная блокада). Умалчивалась информация о ценности горы Куштау, не уточнялось, что гора имеет всемирное геологическое значение, важное региональное природное, экологическое, рекреационное значение, не уделялось внимание ее эстетической ценности. Также не поднимался вопрос об экологических последствиях возможной разработки: появление очередного карьера, рост отвалов горных пород, влияние разработки на жизнь населения (звуки взрывов, шум и грязь от проезжающих через населенные пункты самосвалов), угроза загрязнения протекающей вдоль склонов реки, изменение розы ветров, климата и экологического состояния близрасположенного промышленного города Стерлитамака (который получал свежий воздух от леса на горе). Никак не обсуждалась культурно-историческая ценность горы: нахождение на горе памятников археологии 4-тысячелетнего возраста, историческая связь горы с событиями времен Великой Отечественной войны (расположение у горы госпиталя для раненых, отправка солдат на фронт от подножья горы).

Смещение акцентов. Наличие возможностей обеспечить производство соды путем использования альтернативной безызвестняковой технологии всячески отодвигалось на второй план и преподносилось как невозможное в силу отсутствия соответствующих финансовых возможностей предприятия или некорректности разработки.

Ну, холм как холм, таким он всегда и был, - Р. Мурзагулов, председатель совета директоров АО «Башинформ» [Член Общественной палаты 2020].

Эти горы - достояние республики, и они сохранятся в первозданном виде. градообразующее предприятие должно жить и работать, а критический момент для принятия решения уже настал. Поэтому мы будем искать сырье для Соды. Что касается горы Куштау, то охранного статуса у нее нет, разрешительные документы на начало разработки выданы еще в 2017 году и работы уже ведутся. Если запасы здесь подтвердятся - это приемлемый вариант решения проблемы, - глава Республики Башкортостан Р. Хабиров [Хабиров 2018].

Образ врага. Защитников Куштау пытались выставить шовинистами, экстремистами, ваххабитами, экотеррористами. Членов башкирской национальной организации называли экстремистами еще до вступления в силу решения суда о признании организации экстремисткой. Особая группа обвинений была связана с продажностью активистов, якобы их 
финансируют компании-конкуренты (например, группа компаний «ТАУ») или даже страны-конкуренты (Турция). При этом обвинения не сопровождались доказательствами.

О чем нам вступать в диалог с протестующими? Там же почти все экстремистьы, - заявил Р. Басыров (замдиректор АО «Башкирская содовая компания») [Лотфуллина 2020].

Экстремисть, те, кто пьтается расшатать ситуачию, - все здесь собрались, потому что увидели здесь точку напряжения. Они хотят расшатать нашу республику, - гендиректор АO «Башкирская содовая компания» Э. Давыдов [Блажнова 2020].

Вы спрашиваете у меня, дорогая Айгуль, были ли экстремисть на Куштау... конкретные имена вам раскроют. Очень скоро. Компетентные органы. Которые уже собрали много отличного материала, чтобы расисты наконеи, то получили своё, - Р. Мурзагулов, председатель совета директоров АО «Башинформ» [Мурзагулов 2020].

По ее словам [главы профсоюза Гузель Мирошниченко], среди противников БСК - ваххабить, националисты и сторонники Алексея Навального [Столкновения у горы 2020].

Некая группа предпринимателей, близкая к прежней власти Башкирии, решила, что сверхприбыли ей тоже не помешают... А Соде было сказано - вы закрывайте свою лавочку. Либо продавайте ее нам, за очень недорого. Либо покупайте у нас Гумеровское месторождение, за очень дорого. Потому как соседние холмы мы вам освоить не дадим. Мы организуем вам там народные протесты... Кого-то подкупили. Кого-то, романтически настроенного, убедили в том, что шиханы - священ$\mathcal{H} b l$, - председатель совета директоров ИА «Башинформ» Р. Мурзагулов [Член Общественной палаты 2020].

Мы говорим: «Быстрее дайте новое месторождение шихана». Что вы думаете? Туриия - главный наш конкурент по кальцинированной соде, приезжает из Туриии мусульманский лидер и говорит: «Это у вас памятник, и это тоже памятник, возьмите месторождение в 75 километрах от ГОКа, проведите железную дорогу». Ну всё, привет. Инвестиционный проект можно зачехлять. Почему? Он просто станет экономически неэффективным по сравнению с нашими конкурентами из Турици. Вот и всё. Поэтому когда мы говорим об экологии, нужно очень тонко и чётко определять - всё-таки это искусственное создание препон от наших конкурентов - а я именно об этом говорю, либо это - действительно создание проблемных моментов для экологии... - 
министр промышленности и торговли России Денис Мантуров на круглом столе Петербургского международного экономического форума [Денис Мантуров 2018].

Подмена понятий. Для выражения мысли использовались понятия, близкие по формулировке к правильным, но отличные по смыслу, что вводило слушателя, читателя в заблуждение.

И мы сочли, что с учетом всех обстоятельств (нет охранного статуса, есть выданное ранее разрешение на разработку) Куштау - оптимальный вариант, - Р. Хабиров на встрече с представителями СМИ в декабре 2018 г. [Степанова 2020].

На момент высказывания была выдана только лицензия от 22.06.2016 на пользование недрами с целевым назначением и видами работ для геологического изучения.

Задача тесников: на основе лесной деклараиии сделать точечную вырубкy, - Р. Басыров, заместитель генерального директора по организационной и кадровой политике АО «Башкирская содовая компания» [Хасанова 2020].

Согласно ст. 17 Лесного кодекса Российской Федерации выделяют рубку выборочную и сплошную. Согласно п. 2.2 и 2.11 «Основных положений по рубкам главного пользования в лесах Российской Федерации», выборочные рубки производятся для своевременного использования древесины и сохранения защитных и средообразующих свойств леса. При сплошных рубках весь древостой на лесосеке вырубается за один прием. На Куштау за один прием были вырублены деревья на определенном участке.

Несмотря на то что в нем действуют различные производства, градообразуюшим предприятием была и остается Башкирская содовая компания (БСК) [Без поддержки социалку 2018].

Согласно ст. 169 Федерального закона от 26.10.2002 № 127-Ф3 (ред. от 31.07.2020) «О несостоятельности (банкротстве)», градообразующими организациями признаются юридические лица, численность работников которых составляет не менее 25 \% численности работающего населения соответствующего населенного пункта. При этом численность населения города Стерлитамак, где расположены заводы АО «Башкирская содовая компания», - более 276 тысяч человек, что более чем в 20 раз больше численности сотрудников компании [Численность населения 2020]. При этом важно отметить, что в российском законодательстве однозначного определения понятия «градообразующее предприятие» не выработано [Бегун 2015]. 


\section{Манипуляции с цифрами}

Она [«Башкирская содовая компания»] насчитьвает около девяти тысяч сотрудников, а с учетом занятых на предприятиях-партнерах, количество человек, которым БСК дает работу, по приблизительным подсчетам достигает более 15 тысяч [Амиров 2018].

Депутат Госдумы от Башкирии Михаил Бугера приводит более точные расчеты.

«Только работающих на предприятии - около 8 тьсяч человек. Если брать с членами семей - вдвое больше. А если брать ветеранов предприятия и тех, кто работает в организациях-смежниках - это около 35 тысяч человек» [Эксперты рассказали 2018].

Размывание определенности. Утверждение сведений, противоречащих фактам или предыдущей информации о возможности разработки Куштау.

Если запасы здесь подтвердятся - это приемлемый вариант решения проблемы, - Глава Республики Башкортостан Р. Хабиров [Хабиров 2018].

По словам Иванова [президента Российского союза химиков, председатель комиссии по химической промышленности, член правления РСПП], предложенное компании для разработки вместо горы Тра-тау альтернативное месторождение [Куштау] действительно не подходит по качеству сырья [Эксперты рассказали 2018].

Использование понятий в значении, отличном от общепринятого, зафиксированного толковыми словарями (например, утверждения о защитниках горы Куштау как о бритоголовых молодчиках, применявших насилие в период 2-6 августа 2020 г.):

Когда на пути нашей техники, наших работников встают молодчики бритоголовые, которье угрожают лесникам физической расправой, которые угрожают насилием, я считаю, что все наши действия вполне оправданы. Там было насилие... Срывали наши аншлаги, ломали стенды инбормационные. Насилие, я, естественно, говорю не в терминологии уголовного кодекса [«Редколлегия» Рустем Басыров 2020].

Прилагательное «бритоголовый» в одном из значений характеризует особенности внешнего вида бандитов, а в другом - человека, принадлежащего к националистической группировке скинхедов [Щетинина 2016]. При этом значение, зафиксированное в словарях литературного языка, которое называет анатомическую характеристику внешности человека, является наименее употребительным. В данном 
случае происходит размывание смысла употребляемого понятия, однако, учитывая контекст, наиболее вероятно восприятие словосочетания «бритоголовых молодчиков» как бандитов. В случае, если автор использовал его в значении бандитов или скинхедов, приводимое высказывание можно также рассматривать в качестве примера прямой лжи, так как в указанные дни не установлено совершение на горе каких-либо преступлений протестующими, скинхедов среди местных жителей и активистов, находящихся на горе, не было.

Прямая ложь. Намеренное искажение фактов, касающихся добычи известняка из горы Куштау.

Никаким образом геологические работы на комборте жителей не повлияет. Пьль вся будет оседать на карьере. Никаких работ в природоохранной зоне и рядом с ней не будет [Хасанова 2020].

Согласно данным кадастровой карты, расстояние от крайних участков с. Бельского, расположенного у подножья горы со стороны планировавшейся добычи, составляет менее 50 м, что повышает вероятность изменения качества жизни в процессе добычи. Предполагалась перевозка известняка на самосвалах, что привело бы к распространению пыли за пределы места добычи. Гора омывается рекой, а значит, добычу предполагалось вести рядом с водоохранной зоной, являющейся частью горы.

Также примером мелкой прямой лжи является утверждение о том, что среди лиц, выражавших несогласие с началом рубки на горе в первые дни, не было местных жителей.

Вся буза началась в понедельник, когда наши лесники, геологи попьтались начать, продолжить разработку, которую они начали. И мы внимательно анализировали и в понедельник, и во вторник, и в последующие дни, кто является ядром организационным, кто входит в актив протестантов - там местных жителей не было. Потом они появлялись, появлялись активисты, мы всех их знаем, мы с ними в общении, в диалоге, но они подошли потом [«Редколлегия» 2020].

Утверждение противоречит реальному положению дел в указанный период времени: лицами, выражавшими несогласие, стали местные жители, что демонстрирует видеоролик, снятый в первый день протеста [Репортаж с места 2020]. 


\section{РЕЗУЛЬТАТЫ ГЛУБИННЫХ ИНТЕРВЬЮ, ПРОВОДИМЫХ С ЖИТЕЛЯМИ ДРУГИХ РЕГИОНОВ, НА ТЕМУ БУДУЩЕГО ШИХАНА КУШТАУ}

Для исследования осведомленности граждан о проблеме были проведены глубинные интервью с выходцами из Башкортостана, проживающими в других регионах России и за ее пределами. Результаты оказались неоднородными. Кто-то узнал о проблеме в момент интервью.

И.: Вы слышали, что гору Куштау хотят использовать для добычи сырья? Что думаете об этом?

Нет, не слышиала. Ю., Санкт-Петербург.

Узнала от вас. Э., Лондон.

И.: Кому-то была известна проблема, предыстория конфликта и другие подробности?

Да, слышил. Категорически против. А., Москва.

Да, сльшила. Большей частью против. М., Берлин.

Сльшиала. Категорически против. О., Байконур.

Про разработку горы Куштау, конечно же, сльшал. Т., Москва.

Сльшиал. Считаю, что это варварство, авторы и бенебициары этой идеи - манкурты и капиталисты без совести и фантазии. Уверен, что «Башкирская содовая компания» может успешно работать и на другом сырье. Э.А., Санкт-Петербург.

Проблема, вызванная истощением ресурсов уже выработанного шихана Шахтау и необходимостью поиска нового источника сырья для производства содьи, вызвала острый общественный резонанс и публичную дискуссию со стороны граждан, власти и бизнес-сообщества. Ими могут оказаться соседние шиханы: Куштау, Юрактау, Тратау. Однако последние два являются действующими памятниками природь, а вопрос качества сырья на шихане Куштау требует дополнительного изучения. В любом случае проблему необходимо рассматривать комплексно, учитьвая, экологический, экономический, сочиальньй аспекты. П.Б., Москва.

Некоторые отвечавшие указывали на наличие альтернативных вариантов решения проблемы предприятия, что показывает хорошую осведомленность в вопросе.

Думаю, что никакая прибыль горстки людей не должна становиться причиной утраты уникальных природньх объектов. Особенно, когда существуют альтернативные источники сырья и методы производства. А.К., Санкт-Петербург. 
Слышала, это очень грустно, да и хватит сырья опять же лет на 50-60, а дальше что? Знаю, что можно без этого обойтись, ну просто для другого пути нужны деньги, а их «большие» люди вкладывать не хотят, легче гору снести... Е., Санкт-Петербург.

Ответы интервьюируемых указали на понимание горы Куштау как ценного природного объекта и желание его сохранить.

Хочу, чтобь, как и мои дети, так и будущие внуки посещали эти красивые и родные места. На Шиханах можно организовать природный памятник. Р.С., Елизово (Камчатский край).

Использовались горы в советское время как объекты культурного и природного наследия, охранялись государством, так и надо использовать. А.П., Санкт-Петербург.

Кто-то полагал, что гора уже находится под защитой государства.

Варварство, думала, что шихан давно сделали памятниками природы. Тем более что там растут растения из Красной книги. Как минимум это один из символов Башкирии и непонятно, как его могли отдать под добычу сырья. Э.Б., Лондон.

Часть интервьюируемых указала на важное значение содового предприятия, одновременно заявив о необходимости всестороннего изучения проблемы и поиска путей сохранения горы при одновременном сохранении работоспособности предприятия.

Башкирские шиханы - уникальное природное явление, однако необходимость добьчи соды также имеет общенациональное значение. Кальиинированная сода используется в металлургической, стекольной, химической и других видах промышленности. Производимый продукт - одна из визитных карточек всей Республики Башкортостан, обеспечивающий экономическую независимость России в этой сфере. Кроме того, добыча соды имеет важное соииальное значение, так как на предприятии работает значительная часть жителей Стерлитамака. В наши дни технологии добычи полезных ископаемых во многом усовершенствовались. Считаю, что при привлечении экспертного сообщества возможным нахождение технологии добычи при минимальном антропогенном воздействии. П.Б., Москва.

Некоторые ответы показали подверженность мифам, распространяемым в СМИ.

К сожалению, многие [в результате разработки Куштау] потеряют рабочие места, а новые в других отраслях не создаются. М., Берлин.

Интервьюируемые отмечали трудности в определении собственного мнения о проблеме вследствие недостаточной информированности. 
Однозначно не могу выразить свое отночение к этому, так как не знаю всех подробностей этой проблемы. Уникальные природные объекты естественно нужно охранять и использовать их только в случае крайней необходимости. Если есть возможность использовать альтернативные источники сырья, то надо изучить этот вопрос и постараться сохранить шиханьл. Т., Москва.

Ответы показали, что граждане считают нужным общественное обсуждение подобных проблем.

Считаю, что каждьй случай требует индивидуального рассмотрения. Такие вопросы надо выносить на всеобщее обсуждение. Ю., СанктПетербург.

Даже осознавая недостаток информации, интервьюируемые отмечали высокую значимость горы Куштау и остальных шиханов.

Это гигантские рифы древнего моря, наше наследие, наша гордость и нигде в мире таких нет! Е., Санкт-Петербург.

Прежде всего для меня шихань - это память и гордость за Родину. Т., Москва.

Для меня башкирские шихань - это мой дом. Я родилась у подножия Куштау, в п. Мебельном. Все детство и юность неразрьвно связано сэтой горой, тесом, произрастающем на шихане и речкой, огибающей Куштау. 3. Сургут.

Шиханы являются символом региона. М., Берлин.

Это коралловые рифы теплого Пермского моря. [Нужно] оставить ее жить своей жизнью в соответствии с законами природы. Так она принесет значительно больще пользы для общества, выполняя функиии от средообразующих до социальных. А., Москва.

Результаты интервью, проведенных спустя пять месяцев после обнародования планов добычи известняка для содового производства из Куштау, показали:

а) недостаточную освещенность проблемы (та как, даже несмотря на то что интервьюируемые были выходцами из Башкортостана и сохраняли связи с регионов, знали об этих планах не все, лишь некоторые могли подробно описать суть ситуации, наличие альтернативных решений);

б) восприятие интервьюируемыми природного объекта как объекта отдыха, охраны природного и культурного наследия, туризма, но не как месторождения полезных ископаемых (в этом все респонденты были солидарны). 


\section{ПРЕОДОЛЕНИЕ ИНФОРМАЦИОННОЙ БЛОКАДЫ И ДРУГИХ МАНИПУЛЯТИВНЫХ ПРИЕМОВ, ИСПОЛЬЗУЕМЫХ В ВОПРОСАХ ОСВЕЩЕНИЯ БУДУЩЕГО ГОРЫ КУШТАУ}

Процесс борьбы за сохранение горы Куштау условно можно поделить на два этапа: «мирный период» (осень 2018 - июль 2020 г.) и «период обострения» (1 августа - 2 сентября 2020 г.). Каждый из периодов имел собственную цель: сначала рассказать о проблеме для создания альтернативного общественного мнения и (привлечь на втором этапе) как можно больше союзников для поддержки гражданских защитников горы. При этом оба этапа в общем виде имели основной целью преодолеть информационную блокаду и одностороннее преподнесение информации о проблеме. Отличие также состояло в том, что в период обострения ситуации освещать требовалось не только саму проблему выбора решения вести добычу на Куштау, но и возникшую реальную угрозу горе, а также активистам, которые ее защищали. Создание лагеря добровольцев, дежуривших у горы, поставило задачу информационной поддержки лагеря для обеспечения его существования до решения проблемы. Отсутствие активистов на природном объекте позволило бы предприятию без промедлений приступить к хозяйственной деятельности, которая бы нарушила целостность природного объекта. Также в «период обострения» добавилась задача сверхоперативного распространения информации о происходящем, та как временная задержка даже на несколько часов могли привести к непоправимым последствиям.

В «мирный период» перед движением стояли следующие задачи:

1) ведение группы в соцсетях: донесение ценности Куштау, способов сохранения шихана, альтернативных (безызвестняковых) технологий производства соды; развенчание мифов; призыв присоединиться к кампании по отправке массовых обращений в органы власти, СМИ, блогерам; презентация видов горы, птиц, животных, растений, сбор фотоснимков;

2) участие в мероприятиях (круглых столах, организованных Советом по правам человека при Президенте РФ, газетой «Bonus», общественностью; форумах: Общероссийский гражданский форум, Международный форум урбанистики в Уфе) для привлечения сторонников в экспертном обществе; 
3) проведение акций - флешмобов: офлайн «Живая цепь» (в декабре 2019 г., январе и феврале 2020 г.), онлайн «МыЗаКуштау» (осень 2019 г.);

4) обращение в природоохранные организации (Европейскую ассоциацию охраны геологического наследия «ProGEO», «Greenpeace», «Движение ЭКА»);

5) обращения и публикации в СМИ, в том числе тематических, косвенно связанных с проблемой («7×7», «Новая газета», «Реальное время», Activatica.org; посвященные путешествиям — «Вокруг света»);

6) работа с мессенджерами (Whats'app): ведение чатов, рассылка сообщений;

7) съемка фото- и видеоматериалов для распространения.

$\mathrm{B}$ «период обострения» стало ясно, что без широкого резонанса лагерь уничтожат до того, как появится возможность правового решения вопроса, и начнется хозяйственная деятельность на горе.

Распространение информации происходило через:

1) СМИ, в том числе иностранные;

2) лидеров общественного мнения, известных медийных личностей (Ю. Шевчук, М. Галкин, С. Казанова, Л. Утяшева, Face), блогеров (I’morganicblog, П. Пашков и др.);

3) обычных граждан (через соцсети, в первую очередь Instagram, «ВКонтакте» и мессенджеры).

Рассылка в СМИ была эффективна в случае отправки краткого описания проблемы, истории спора, приложения фото-, видеокадров, перевода (для иноязычных СМИ).

Очень эффективным стало распространение информации через Instagram, где популярностью пользовались короткие «сторис» текстового формата с описанием ситуации или короткие видео с места событий. Пользователи «скринили» текстовые «сторисы» и размещали их в своих аккаунтах, что создавало эффект «сарафанного радио» и позволяло в короткий срок широко распространить информацию. Также были эффективны простые публикации фото- или видеокадров с развернутым описанием событий, которые другие пользователи «репостили» в своих «сторис». Распространение посредством этого канала позволило донести информацию о ситуации за пределы региона и даже страны.

Через чаты происходило распространение информации об угрозах, постах ДПС, препятствовавших проезду к горе, сигналах тревоги (на- 
падениях на лагерь), задержаниях активистов. Это позволяло своевременно подавать информацию жителям региона.

Для распространения информации в «горячий период» также были актуальны круглые столы в рамках экспертного сообщества, которые были проведены силами газеты «Bonus», КПРФ, Общественной палаты РФ. Любое событие в этот и «мирный период» обретало дополнительное значение создания инфоповода для дальнейшей огласки.

В «горячий период» важным стимулом для распространения информации стало ощущение несправедливости, происходившей в отношении как ценного природного объекта, так и активистов (особенно женщин, пенсионеров). Заграничные флешмобы и пикеты (в Бостоне, Нью-Йорке, Барселоне, Мюнхене), митинг перед штаб-квартирой ООН в Нью-Йорке создавали инфоповоды для иностранных СМИ.

Важно отметить, что эти задачи формировались стихийно, постепенно осознаваясь незнакомыми друг с другом людьми как необходимые действия для достижения конечной цели - сохранения уникального природного объекта.

\section{ЗАКЛЮЧЕНИЕ}

Пример информационной политики, проводимой в отношении судьбы природного объекта горы-шихана Куштау, показал, что манипулирование общественным мнением, касающегося острых экологических проблем, рано или поздно вынуждает граждан бороться за получение достоверной информации. Одновременно использование приемов манипулирования, например замалчивание информации, ее искажение или однобокое освещение ситуации, приводит к усугублению проблемы, провоцирует социальную напряженность, недоверие к СМИ и государству (если оно воздерживается от обсуждения «неудобных» тем). В условиях роста количества точек экологических противостояний в стране это может привести к усилению общественной конфронтации, росту протестных настроений, политической нестабильности. В свою очередь, своевременное освещение экологических проблем, их обсуждение в рамках экспертного сообщества, учет мнения населения, поиск новых способов решения позволят не только предотвратить обострение ситуации, но и снизить вред окружающей среде.

Приведенные в исследовании способы преодоления информационной блокады, а также других манипулятивных приемов, использованные 
в процессе защиты гражданами уникального остатка рифового массива Куштау, выявили возможность создания силами гражданского общества альтернативного, более объективного информационного потока. Широкое освещение проблемы в социальных сетях не только помогло мобилизовать граждан к выражению своего мнения и защите горы, но и привлекло внимание независимых СМИ. Огласка проблемы на федеральном и даже международном уровне сыграла одну из ключевых ролей в последующем решении о сохранении горы и обеспечении Куштау защиты путем создания на ее землях особо охраняемой природной территории.

Вопросы защиты окружающей среды - одно из важнейших направлений деятельности государства, поскольку от ее состояния зависит жизнь каждого человека. Поверхностное, небрежное (намеренное или случайное) отношение к информации в отношении вопросов экологии должно уступить место разумному, бережному соучастию, которое станет залогом успешного развития общества и его экологического благополучия.

\section{Литература}

Бегун T.B. Градообразующее предприятие: понятие, критерии отнесения, классификация // Инновационная экономика: перспективы развития и совершенствования. 2015. № 2 (7). С. 36-41.

Горина Е.B. Коммуникативные технологии манипуляции в СМИ и вопросы информационной безопасности. Екатеринбург: Урал, 2016. 67 с.

Зелинский C.A. Манипуляции массами и психоанализ. Манипулирование массовыми психическими процессами посредством психоаналитических методик. СПб.: Скифия, 2008. 248 с.

Кара-Мурза С.Г. Манипуляция сознанием. Век XXI. М.: Алгоритм, 2015. 219 c.

Ноэль-Нойман Э. Общественное мнение. Открытие спирали молчания. М.: Прогресс-Академия, 1996. 352 с.

Черникова B.E. Манипуляция массовым сознанием как феномен информационного общества // Теория и практика общественного развития. 2015. № 3. URL: http://teoria-practica.ru/rus/files/arhiv_zhurnala/2015/3/philosophy/ chernikova.pdf (дата обращения: 15.08.2020). 


\section{Источники}

Амиров А. Без поддержки социалку не поднять // Интернет-портал «Российской газеты». 25.02.2018. URL: https://rg.ru/2018/10/25/ reg-pfo/s-zakrytiem-bsk-v-sterlitamake-mogut-svernut-socialnye-programmy. html (дата обращения: 25.12.2018).

Башкириев Р. Денис Мантуров: У нас до сих пор проходят баталии в Башкирии по соде // Mkset: новости Уфы и Башкирии. 24.05.2018. URL: https://mkset. $\mathrm{ru} /$ news/economy/24-05-2018/denis-manturov-u-nas-do-sih-por-prohodyat-bataliiv-bashkirii-po-sode (дата обращения: 25.12.2018).

Беляев А. Римма Утяшева о Торатау: «Наконец-то в этом деле поставлена точка» // Bash.News - Актуальные новости Уфы и Республики Башкортостан, аналитические материалы, обзорные статьи и мнения специалистов. 9.12.2018 URL: https://bash.news/news/85804-rimma-utyasheva-o-toratau-nakonets-to-vetom-dele-postavlena-tochka (дата обращения: 25.12.2018).

Блажнова О. Гора непонимания. Что дали протесты защитников шихана Куштау в Башкирии // Аргументы и Факты. 17.08.2020. URL: https:/ufa.aif.ru/ society/details/gora_neponimaniya_chto_dali_protesty_zashchitnikov_shihana_ kushtau_v_bashkirii (дата обращения: 17.08.2020).

В Башкортостане создадут рабочую группу по вопросам промышленной разработки шихана Куштау // Официальный сайт главы Республики Башкортостан. 13.02.2020 https://glavarb.ru/rus/press_serv/novosti/130574.html (дата обращения: 15.08.2020).

Грей Э. // ВКонтакте. 16.08.2020. URL: https://vk.com/ elvingrey?w=wall3856851_342517 (дата обращения: 15.08.2020).

Жировкин А. «Сода» растворилась. Главный тренер «Содовика» Александр Игнатенко: Почему убили «Содовик»? // Советский спорт. 18.12.2006. URL: https://www.sovsport.ru/football/articles/245395-soda-rastvorilas-glavnyj-trenersodovika-aleksandr-ignatenko-pochemu-ubili-sodovik (дата обращения: 17.08.2020).

Лотфуллина Д. В БСК активистов на шихане Куштау назвали экстремистами // ProUfu.ru. 7.08.2020. URL: https://proufu.ru/news/spec/kushtau/95221-v_ bsk_aktivistov_na_shikhane_kushtau_nazvali_ekstremistami/ (дата обращения: 15.08.2020).

Мурзагулов Р. // Facebook. 23.09.2020. URL: https://www.facebook.com/ moorross (дата обращения: 15.10.2020).

На средства БСК Фонд социальных программ РБ профинансировал новогоднее украшение Стерлитамака // БСК. 13.12.2019. URL: https://www.soda.ru/ ru/news/detail/1243/ (дата обращения: 10.04.2020).

«Редколлегия». Рустем Басыров, Наталья Павлова, Артур Асафьев, Руслан Валиев // Эхо Москвы в Уфе. You-tube-видеохостинг. 7.08.2020 URL: https:// www.youtube.com/watch?v=h4vOmYuyzYM (дата обращения: 15.08.2020). 
Репортаж с места событий с охраной БСК-Сырьевая компания и лесниками на Куштау. 03.08.2020 г. // Night Ufa. You-tube-идеохостинг. 3.08.2020 URL: https://www.youtube.com/watch?v=OOf_sCIEpIc (дата обращения: 3.08.2020).

Семина М. Грант БСК позволил вывести спортивные соревнования на новый уровень // Mkset: новости Уфы и Башкирии. 12.12.2018. URL: https://mkset. ru/news/sport/12-12-2018/grant-bsk-pozvolil-vyvesti-sportivnye-sorevnovaniya-nanovyy-uroven (дата обращения: 10.04.2020).

Социальная политика БСК: итоги года // Mkset: новости Уфы и Башкирии. 26.12.2017. URL: https://mkset.ru/article/tilda/26-12-2017/blagie-dela-bashkirskoysodovoy-kompanii (дата обращения: 10.04.2020).

Столкновения у горы Куштау: задержаны 25 активистов // Радио Свобода. 15.08.2020. URL: https://www.svoboda.org/a/30785398.html (дата обращения: 15.08.2020).

Степанова A. Скандал вокруг шиханов: Куштау — новый «Шиес»? // ИА REGNUM. 13.08.2020. URL: https://regnum.ru/news/society/3035476.html (дата обращения: 15.08.2020).

Численность населения Российской Федерации по муниципальным образованиям (на 01.01.2020) // Росстат. URL: https://rosstat.gov.ru/storage/ mediabank/CcG8qBhP/mun_obr2020.rar (дата обращения: 15.08.2020).

Член Общественной палаты России: «Ситуация вокруг Куштау - очень простая» // Башинформ. 10.08.2020 URL: https://www.bashinform.ru/m/ news/1480890-chlen-obshchestvennoy-palaty-rossii-situatsiya-vokrug-kushtauochen-prostaya/ (дата обращения: 15.08.2020).

Фатхуллина Н. «Деньги ведь не пахнут»: позиция лидеров мнений Башкирии по поводу разработки Куштау // ProUfu.ru. 14.08.2020. URL: https://proufu. ru/news/spec/kushtau/95428-dengi_ved_ne_pakhnut_pozitsiya_liderov_mneniy_ bashkirii_po_povodu_razrabotki_kushtau/ (дата обращения: 15.08.2020).

Хабиров P. // Instagram. 7.12.2018 URL: https://www.instagram.com/p/BrFoA RCAC8L/?igshid=k3zg6dx3dlf7 (дата обращения: 7.012.2018).

Хабиров Р. Послание Государственному Собранию - Курултаю Башкортостана // Официальный сайт главы Республики Башкортостан. 10.12.2019. URL: https://glavarb.ru/rus/press_serv/novosti/128798.html (дата обращения: 10.12.2019).

Хасанова А. Правда о разработке Куштау: что происходит на горе в Башкирии // Благоварские вести. 10.08.2020. URL: https://blagovar-vesti.rbsmi.ru/ articles/aktualno/Pravda-o-razrabotke-Kushtau-chto-proishodit-na-gore-vBashkirii-403404/ (дата обращения: 15.08.2020).

Чернова С. Пришли к компромиссу: БСК возьмет в разработку один из шиханов // Уфа1.pу. 7.12.2018. URL: https://ufa1.ru/text/economics/65711401/ (дата обращения: 10.04.2020).

Эксперты рассказали о последствиях закрытия содового завода в Башкирии // Россия сегодня. 31.07.2018 (обновлено 03.03.2020). URL: https://ria. ru/20180731/1525698563.html (дата обращения: 15.08.2020). 


\section{MANIPULATION OF PUBLIC OPINION IN ENVIRONMENTAL CONFLICT IN KUSHTAU \\ K. Gorbacheva}

(carriestr@gmail.com)

Inter-regional environmental public organization "Eka»,

Moscow, Russia

Citation: Gorbacheva K. Manipulyatsii obshchestvennym soznaniyem $\mathrm{v}$ ekologicheskom konflikte na Kushtau [Manipulation of public opinion in environmental conflict in Kushtau]. Vlast' i elity [Power and Elites], 2020, 7 (1): 204-231. (In Russian)

DOI: https://doi.org/10.31119/pe.2020.7.1.8

Abstract. The article describes the results of a study of civil protest in the Republic of Bashkortostan against the destruction of the mountain-Shikhan Kushtau, which is a world geological heritage. The subject of the research is manipulation of public consciousness in environmental conflict and their overcoming. The research is based on the theory of manipulation of public consciousness, which explains the achievement of a certain level of consent in society and passive behavior in a situation of social conflict through the use of manipulative techniques in information policy. The author analyzes the different channels of dissemination of information on the topic of Kustow on the presence in them of signs of the use of manipulative techniques. Materials in the media and other information sources were also analyzed to determine whether the images of the situation offered by various actors correspond to the real state of Affairs. Manipulation techniques are systematized. Data from in-depth interviews were analyzed to determine the level of awareness of natives of Bashkortostan, now living in other Russian cities, about the problem of industrial development of Shikhan Kushtau. The mechanism of overcoming manipulative influence used by the public movement in defense of Kushtau was considered, which eventually led to the decision of the authorities to preserve the mountain and provide it with state protection.

Keywords: manipulation of public opinion, mass consciousness, information distribution channels, mass media, environmental movement, civil society, network participation. 


\section{References}

Begun T.V. Gradoobrazuyushcheye predpriyatiye: ponyatiye, kriterii otneseniya, klassifikatsiya [City-forming enterprise: concept, criteria for assignment, classification], Innovatsionnaya ekonomika: perspektivy razvitiya i sovershenstvovaniya [Innovative economy: prospects for development and improvement], 2015, 2 pp. 36-41. (In Russian)

Chernikova V.Ye. Manipulyatsiya massovym soznaniyem kak fenomen informatsionnogo obshchestva [Manipulation of mass consciousness as a phenomenon of the information society], Teoriya i praktika obshchestvennogo razvitiya [Theory and practice of social development], 2015, 3. Available at: http://teoria-practica.ru/ rus/files/arhiv_zhurnala/2015/3/philosophy/chernikova.pdf (accessed: 15.08.2020). (In Russian)

Chislennost' naseleniya Rossiyskoy Federatsii po munitsipal'nym obrazovaniyam na 1 yanvarya 2020 goda [The population of the Russian Federation by municipalities as of January 1, 2020], Web-site Rosstat [Federal State Statistics Service]. Available at: https://rosstat.gov.ru/storage/mediabank/CcG8qBhP/mun_obr2020.rar (accessed: 15.08.2020). (In Russian)

Gorina Ye. V. Kommunikativnyye tekhnologii manipulyatsii v SMI $i$ voprosy informatsionnoy bezopasnosti [Communicative technologies of manipulation in the media and issues of information security]. Yekaterinburg: Ural, 2016. 67 p. (In Russian)

Kara-Murza S.G. Manipulyatsiya soznaniyem. Vek XXI [Manipulation of consciousness. XXI Century]. Moscow: Algoritm, 2015. 219 p. (In Russian)

Noel'-Noyman E. Obshchestvennoye mneniye. Otkrytiye spirali molchaniya [Public opinion. Opening a spiral of silence]. Moscow: Progress-Akademiya, 1996. 352 p. (In Russian)

Zelinskiy S.A. Manipulyatsii massami i psikhoanaliz. Manipulirovaniye massovymi psikhicheskimi protsessami posredstvom psikhoanaliticheskikh metodik [Mass manipulation and psychoanalysis. Manipulation of mass mental processes through psychoanalytic techniques]. St. Petersburg: Skifiya, 2008. 248 p. (In Russian) 